\section{KETEPATAN MODEL ALTMAN, SPRINGATE, ZMIJ EWSKI, DAN GROVER DALAM MEMPREDIKSI FINANCIAL DISTRESS}

\author{
Edi dan May Tania \\ Program Studi Akuntansi Universitas Internasional Batam \\ J In. Gajah Mada, Batam, Indonesia \\ Email: edi.king@uib.ac.id
}

diterima 10 November 2017, direview 15 November 2017, direvisi 17 November 2017, diterima 13J anuari 2018.

Artikel ini tersedia di website http://ejournal.umm.ac.id/index.php/jrak Doi: $10.22219 /$ jrak.v8i1.28

\begin{abstract}
A B ST RACT
This study aims to identify and analyze the accuracy models of financial distress between the model results of Altman, Springate, Zmijewski, and Grover. The model used by investors, creditors and the company itself who will invest in the company and evaluate the financial performance. Samples from this study are 1.321 firm-year, collected from Indonesia Stock Exchange for the period 2012-2016 and were selected using purposive sampling method. The data used in this study are financial reports of each company. The data obtained were tested with logistic regression. This study shows that the model of Altman, Springate, Zmijewski, and Grover has a si gnificant impact and can be used for predicting the condition of financial distress. However, the Springate model is the most appropriate model for predicting the condition of financial distress because it has the highest level of coefficient determination compared to other models.
\end{abstract}

Keywords: Financial Distress, Altman, Springate, Zmijewski, Grover

\section{PE NDAH UL UAN}

Perusahaan membutuhkan sumber dana untuk keberlangsungan aktivitas perusahaan. Perusahaan yang ter daftar pada Bursa Efek biasanya memanfaatkan pasar modal untuk mendapatkan sumber dana. Kinerja maupun kondisi keuangan suatu perusahaan tercerminkan pada pasar modal, peningkatan harga saham akan terjadi jika kinerja perusahaan dan kondisi keuangan membaik.

Kebutuhan mengenai analisis dan prediksi kondisi keuangan menjadi sangat penting tidak hanya bagi investor maupun kreditor, tetapi juga bagi perusahaan itu sendiri untuk mengevalusai kinerja perusahaan. Analisis ini berguna untuk mengantisipasi terjadinya kebangkrutan di masa yang akan datang. Kondisi keuangan perusahaan akan menunjukkan bagaimana tingkat kesehatan keuangan perusahaan. Kondisi keuangan perusahaan dapat diketahui dengan cara menganalisis laporan keuangan perusahaan (Brimantyo, Topowijono \& Husaini, 2012)

Kegagalan keuangan dapat berupa kebangkrutan atau kepailitan. Kepailitan berarti perusahaan tidak dapat memenuhi kewajibannya saat ini karena current liabilities melebihi current asset. (Mohammed \& Soon, 2012). Menurut Platt dan Platt (2002) mendefinisikan kesulitan keuangan merupakan tahap penurunan kondisi keuangan yang terjadi sebelum kebangkrutan ataupun likuidasi. Tirapat dan Nittayagasetwat (1999) mengatakan bahwa perusahaan mengalami kesulitan keuangan apabila perusahaan menghentikan operasi nya dan perusahaan merencanakan untuk melakukan restrukturisasi. Kesulitan keuangan terjadi sebelum kebangkrutan. Model financial distress perlu untuk dikembangkan, karena dengan mengetahui kondisi kesulitan keuangan perusahaan sejak dini di harapkan dapat dilakukan tindakan-tindakan untuk mengantisipasi kondisi yang mengarah pada kebangkrutan (Almilia \& Kristijadi, 2003).

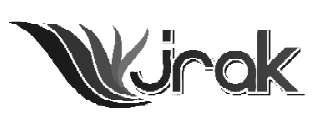

Jurnal Reviu Akuntansi dan Keuangan

p-ISSN : 2615-2223 e-ISSN : 2088-0685 Vol. 8 No. 1, April 2018 Pp 79-92 
Ketepatan

Model

Altman, Springate,...

80
Kebanyakan model prediksi financial distress secara statistik telah dikembangkan dan diuji di negara-negara maju. Di antara berbagai model yang paling umum adalah model Altman Z-Score, yang telah dimodifikasi sebanyak dua kali (Alareeni, Bahaeedin \& Branson, 2013). Model kesulian keuangan telah banyak dikembangkan oleh para peneliti terdahulu untuk mengetahui tingkat kinerja keuangan suatu perusahaan. Para peneliti ini seperti, Fuzzy (1965), Beaver (1966), Altman (1968, 1984, 2000), Springate (1978), Zmijewski (1983) dan Grover (2001).

Banyak literatur yang menggunakan model financial distress untuk memprediksi kebangkrutan perusahaan, namun masih sedikit penelitian yang membandingkan model prediksi financial distresss manakah yang tepat digunakan. Penelitian terdahulu telah melakukan perbandingan ketepatan model menggunakan beberapa model financial distress, seperti yang dilakukan ol eh Gunathilaka (2014) menggunakan 82 sampel perusahaan yang terdaftar di Colombo Stock Exchange selama tahun 2008 sampai 2012 untuk menguji prediksi kebangkrutan menggunakan model Altman dan Springate. Kedua model menunjukkan hasil yang yan tidak jauh berbeda, tetapi model Altman memiliki nilai yang lebih tinggi dan dapat digunakan untuk memprediksi kebangkrutan.

Permana, Ahmar dan, Djadang (2017) membandingkan model Grover, Springate, dan Zmijewski, hasilnya model Springate merupakan model prediksi terbaik. Layyinaturrobaniyah dan Dewi (2017) membandingkan model Altman dan Zmijewski pada perusahaan manufaktur yang terdaftar di BEI, hasilnya model Zmijewski memiliki tingkat akurasi tertinggi sebesar 68\%. Aminian, Mousazade dan Khoshkho (2016) melakukan penelitian menggunakan model Altman, Springate, Zmijewski dan Grover untuk meneliti akan kemungkinan terjadinya kondisi financial distress pada perusahaan yang terdaftar di Tehran Stock Exchange, hasilnya model Grover merupakan model terbaik.

Penelitian ini membandingkan model-model prediksi financial distress yang lebih bervariatif dengan menggunakan empat model prediksi. Model-model tersebut mempunyai pengukuran yang beda dan bisa tepat digunakan pada kondisi tertentu.

\section{LANDASAN TEORI DAN PENGEMBANGAN HIPOTESIS}

\section{Financial Distress}

Aghajani dan J ouzbarkand (2012) merumuskan bahwa financial distress adalah situasi dimana perusahaan atau seseorang sedang berada dalam kondisi posisi keuangan yang lemah. Perusahaan ataupun entitas lain tidak dapat membayarkan utang yang dipinjam dari kreditor. Anggarini dan Ardiyanto (2010) menyatakan bahwa perusahaan yang mengalami financial distress akan menghadapi beberapa kondisi. Kondisi yang pertama yaitu perusahaan mengalami kegagalan pembayaran kembali utang yang sudah jatuh tempo kepada kreditur. Kondisi yang kedua yaitu perusahaan tersebut berada dalam kondisi yang tidak solvable yaitu ketidakmampuan seseorang atau badan untuk membayar utang tepat pada waktunya atau keadaan yang menunjukkan jumlah kewaji ban melebi hi harta.

\section{Model Altman terhadap Financial Distres}

Edward Altman merupakan seoarang ekonom dan profesor di New York's Stern School of Business dan mengembangkan model Altman pada tahin 1968. Model Altman kemudian diterima oleh auditor dan manajemen akuntan pada pertengahan tahun 1980. Pada mulanya Altman mengembangkan model berdasarkan perusahaan manufaktur, kemudian selanjutnya dilakukan modifikasi dan untuk sektor tertentu. (AI-Sulaiti \& Almwajeh, 2007). 
Ketepatan dalam memprediksi kebangkrutan pada awal penelitian tahun 1968 yang dilakukan ol eh Altman mencapai $72 \%$ pada dua tahun sebelum pailit. Sementara itu Altman kembali melakukan serangkaian penelitian berikutnya yang meliputi tiga periode waktu yang berbeda sampai dengan tahun 1999 dan hasil kekakuratan dalam memprediksi kebangkrutan pada perusahaan satu tahun ke depan sebesar mencapai $80-90 \%$. M odel Z-Score menjadi al at yang paling banyak digunakan bagi akuntan, auditor dan kreditor untuk mengevaluasi pinjaman sejak tahun 1985 sampai sekarang (Eidleman, 1995).

Diakomihal is (2012) Model pertama yang dilakukan ol eh Altman berdasarkan data dari perusahaan manufaktur yang tel ah go-public, sedangkan versi modifikasi yang dilakukan oleh Altman selanjutnya dirancang untuk dapat diterapkan pada perusahaan industri swasta dan perusahaan non-industri, serta perusahaan sektor jasa. Penggunaan model Altman telah dilakukan dalam beberapa keadaan dan negara tertentu seperti yang dilakukan ol eh Reddy dan Prasad (2011) melakukan penelitian tingkat kesehatan pada Bank HDFC untuk mengetahui pengaruh dari gabungan beberapa rasio keuangan dengan menggunakan Altman, penelitian dilakukan dari tahun 2006 sampai 2010. Tyagi (2014) melakukan penelitian untuk mengukur tingkat kesehatan perusahaan pada industri logistik di India menggunakan model Altman.

Hayes, Hodge, dan Hughes (2010) melakukan penelitian mengenai ketepatan metode Z-Score dalam memprediksi kebangkrutan pada perusahaan retail dalam jangka waktu 2 tahun, dan hasilnya memiliki ketepatan prediksi sebesar $94 \%$. Prabowo dan Wibowo (2015) melakukan penelitian perbandingan antara model Altman, Zmijewski, dan Grover pada perusahaan delisting yang terdaftar di BEI. Hasilnya model Altman merupakan model terbaik. adalah:

Berdasarkan penelitian sebel umnya, maka hi potesis pertama yang diajukan

$\mathrm{H}_{1}$ : Model Altman berpengaruh signifikan dalam memprediksi financial distress pada perusahaan.

\section{Model Springate terhadap Financial Distres}

Model ini diperkenalkan oleh Gordon L.V. Springatepada tahun 1978. Metode ini merupakan pengembangan dari model Altman. Pada awal nya model ini menggunakan 19 rasiokeuangan populer namun, setelah melakukan pengujian kembali akhirnya Springate memilih 4 rasio yang digunakan dalam menentukan kriteria perusahaan termasuk dalam kategori perusahaan yang sehat atau perusahaan yang berpotensi bangkrut. Model ini memiliki keakuratan 92,5\% dengan menggunakan 40 perusahaan sebagai sampel yang digunakan oleh Springate(Rajasekar, Ashraf \& Deo, 2014)

Sunaryo (2013) penelitian ini untuk memahami apakah model Springate dan model Altman dapat digunakan untuk memprediksi delisting antara model Springate dan model Altman untuk kelompok perusahaan industri. Hasil penelitian ini mejelaskan bahwa baik model Springate maupun model Altman dapat digunakan untuk mempredi ksi delisting. Permana, Ahmar, dan Djadang (2017) menguji perbedaan antara model Grover, Springate, dan Zmijewski. Penelitian ini berfokus pada sektor manufaktur dengan hasil model Springate sebagai model prediksi terbaik. Meiliawati (2016) melakukan penelitian untuk mengetahui apakah terdapat perbedaan hasil prediksi financial distress antara model Altman dan Springate pada sektor perusahaan kosmetik yang terdaftar di BEI, hasilnya Springatemerupakan model terakurat dengan akurasi sebesar $91,66 \%$ sedangkan Altman sebesar $60,41 \%$. adalah:

Berdasarkan penelitian sebel umnya, maka hi potesis pertama yang diajukan

$\mathrm{H}_{2}$ : Model Springate berpengaruh signifikan dalam memprediksi financial distress pada perusahaan. 
Ketepatan

Model

Altman, Springate,...

82

\section{Model Zmijewski terhadap Financial Distres}

Zmijewski mengembangkan model prediksi kebangkrutan pada tahun 1984. Model tersebut menggunakan rasio keuangan yang mengukur kinerja keuangan, leverage, dan likuiditas perusahaan. (Qisthi, Suhadak \& Handayani, 2012). Layyinaturrobaniyah dan Dewi (2017) membandingkan model Altman dan Zmijewski pada perusahaan manufaktur yang terdaftar di BEI, hasilnya model Zmijewski memiliki tingkat akurasi tertinggi sebesar 68\%. Husein dan Pambekti (2014) menganal isis keakuratan model Altman, Springate, Zmijewski, dan Grover sebagai prediktor terbaik kesulitan keuangan. Sampel terdiri dari 132 perusahaan yang terdaftar di Daftar Efek Syariah, hasil nya model Zmijewski merupakan model yang paling tepat.

Sinarti dan Sembiring (2015) melakukan penelitian akan prediksi kebangkrutan pada perusahaan manufaktur di BEI dengan menggunakan tiga model, yaitu Altman, Springatedan Zmijewski. Ketiga model tersebut memiliki perbedaan hasil, ini dikarenakan perbedaan komponen dalam perhitungan kebangkrutan. Perbedaan yang signifikan pada model Zmijewski karena adanya profit after tax, total assets, total debt, dan current debt. adalah:

Berdasarkan penel itian sebel umnya, maka hi potesis pertama yang diajukan

$\mathrm{H}_{3}$ : Model Zmijewski berpengaruh signifikan dalam memprediksi financial distress pada perusahaan.

\section{Model Grover terhadap Financial Distres}

Model Grover dikembangkan pada tahun 2001 dan merupakan model turunan dari model Altman dengan melakukan penilaian ulang yang dilakukan oleh J effrey S. Grover. Putra dan Septiani (2017) melakukan penelitian mengenai analisis perbandingan model Zmijewski dan Grover pada perusahaan semen yang terdaftar di BEI, hasilnya terdapat perbedaaan antara kedua model tersebut. Hastuti (2014) melakukan penelitian untuk melakukan analisis komparasi model financial distress Altman, Springate, Grover, dan Ohlson pada perusahaan manufaktur di BEI. Kesimpulan dari penelitian ini menunjukkan perbedaan yang signifikan pada setiap model dan tingkat akurasi tertinggi adalah model Grover. Prihantini dan Sari (2013) meneliti kebangkrutan pada perusahaan food and beverage yang terdaftar di BEI menggunakan model Altman, Springate, Zmijeski dan Grover. Hasilnya model Grover merupakan model terbaik disusul Springate, Zmijewski lalu Altman. adalah:

Berdasarkan penelitian sebel umnya, maka hi potesis pertama yang diajukan

$\mathrm{H}_{4}$ : Model Grover berpengaruh signifikan dalam memprediksi financial distress pada perusahaan.

Penelitian ini juga bertujuan untuk mengetahui model terbaik dalam memprediksi financial distress. Sehingga hi potesis dapat dirumuskan sebagai berikut:

$\mathrm{H}_{5}$ : Altman merupakan model prediktor yang paling tepat diantara model Springate, Zmijewski dan Grover.

$\mathrm{H}_{6}$ : Springate merupakan model prediktor yang paling tepat diantara model Altman, Zmijewski dan Grover.

$\mathrm{H}_{7}$ : Zmijewski merupakan model prediktor yang paling tepat diantara model Altman, Springate dan Grover.

$\mathrm{H}_{8}$ : Grover merupakan model prediktor yang paling tepat diantara model Altman, Springate dan Zmijewski. 


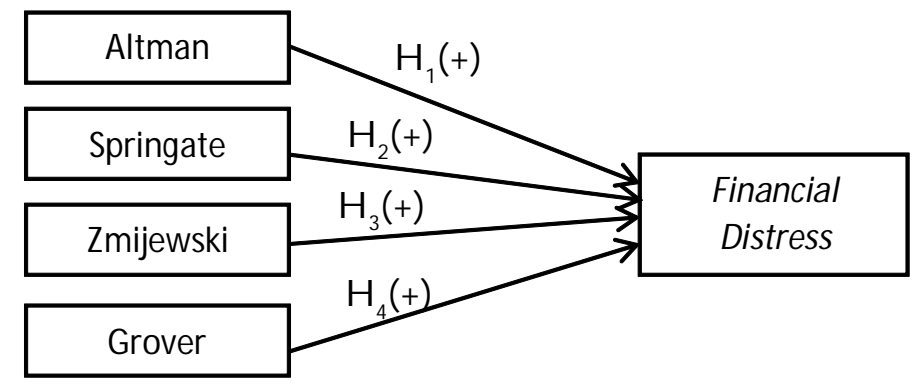

\section{METODE PENELITIAN}

Penelitian ini dilakukan dengan menggunakan penelitian deskriptif kuantitatif, bagian ini berisi tentang definisi operasional variabel serta pengukurannya dan teknik analisis data.

\section{Definisi Operasional dan Pengukuran Variabel}

Variabel dependen dalam penelitian ini adalah financial distress, sedangkan variabel independen adalah model Altman, Springate, Zmijewski, dan Grover. Definisi operasional dan pengukuran variabel akan diuraikan sebagai berikut

\section{Financial Distress}

Kriteria dalam menentukan apakah suatu perusahaan mengalami kesulitan keuangan atau dalam kondisi sehat tidak hanya berfokus pada satu kriteria saja, dikarenakan belum adanya teknik spesifik yang konsisten. Perusahaan mengalami financial distress atau tidak dilakukan dengan melihat apabila perusahaan memililiki ekuitas negatif yaitu total hutang melebihi total asetnya atau perusahaan memilik net incomenegatif selama dua tahun berturut-turut (Luciana \& Kristijadi, 2003; Layyinaturrobaniyah \& Dewi, 2017; Gunawan, Pamungkas \& Susilawaati, 2017). Sheikhi, Shams, dan Sheikhi (2012) menentukan financial distress apabila perusahaan kehilangan setidaknya setengah dari modal mereka dua tahun berturutturut.

Pada penelitian ini penulis menggunakan pengukuran yang digunakan ol eh Husein dan Pambekti (2014), dalam menentukan financial distress adalah dengan menggunakan rasio return on equity terhadap $\mathrm{BI}$ rate. Pengukuran dependen dalam penelitian ini dengan variabel dummy. Apabila nilai ROE lebih besar dari $\mathrm{BI}$ rate pada tahun bersangkutan maka perusahaan dikatakan sehat atau tidak mengalami kesulitan keuangan dan diberi angka 0, sebaliknya apabila nilai ROE lebih kecil dari BI rate pada tahun bersangkutan maka perusahaan berada dalam kondisi kesulitan keuangan dan diberi angka 1.

\section{Model Altman}

Hastuti (2014) Model Z-Score pertama kali diperkenalkan oleh Edward I. Altman pada 1968, bahwa perusahaan dengan profitabilitas yang rendah sangat berpotensi mengalami kebangkrutan. Cara untuk mengukur variabel Altman ZScore adalah sebagai berikut:

$Z=1.2 Z 1+1.4 Z 2+3.3 Z 3+0.6 Z 4+0.999 Z 5$

Keterangan:

Z1 =Working capital/Total asset

Z2 = Retained earnings/Total asset
Gambar 1

Analisis Ketepatan Model Altman,

Springate, Zmijewski, dan

Grover dalam

memprediksi

Financial Distress

\section{3}


Ketepatan

Model

Altman, Springate,...

84

$\mathrm{Z3}=$ Earnings before interest and taxes/Total asset

Z4 =Market capitalization/Book value of liabilities

$\mathrm{Z5}=$ Sales/Total asset

Kriteria memprediksi kebangkrutan pada model Z-Score jika nilai $Z<1,8$; maka termasuk perusahaan financial distress, sedangkan jika nilai Z antara 1,81 sampai 2,99; maka termasuk dalam perusahaan grey area (dalam kondisi kritis) dan jika nilai Z >2,99 maka termasuk perusahaan sehat (Diakomi halis, 2012).

\section{Model Springate}

Persamaan model yang dikemukakan oleh Springate adalah:

$\mathrm{S}=1.03 \mathrm{~A}+3.07 \mathrm{~B}+0.66 \mathrm{C}+0.4 \mathrm{D}$

Keterangan:

A $=$ Working capital/Total asset

$B \quad=$ Net profit before interest and tax/Total asset

C $=$ Net beforetaxes/Current liabilities

D $=$ Sales/Total assets

Kriteria untuk persamaan model Springate ini adalah jika nilai $Z<0,862$ maka tergolong perusahaan bangkrut dan apabila nilai $Z>0,862$ maka perusahaan dikategorikan termasuk perusahaan sehat (Rhomadhona, 2014).

\section{Model Zmijewski}

Model yang berhasil dikembangkan oleh Zmijewski yaitu:

$\mathrm{X}$-Score $=-4.3-4.5 \mathrm{X} 1+5.7 \mathrm{X} 2-0.004 \times 3$

Keterangan:

$\mathrm{X} 1=$ Return on asset (ROA)

$\mathrm{X} 2=$ Total liabilities/total assets (Leverage)

X3 $=$ Current assets/Current liabilities

Apabila skor yang di hasilkan lebih dari 0 (nol) maka perusahaan diprediksi akan mengalami kebangkrutan, tetapi jika skor kurang dari 0 (nol) maka perusahaan diprediksi tidak berpotensi mengalami kebangkrutan (Grice\& Dugan, 2003).

\section{Model Grover}

Persamaan model yang dikemukakan oleh Grover adalah:

$\mathrm{G}=1,650 \times 1+3,404 \times 2-0,016 \mathrm{ROA}+0,057$

Keterangan:

$\mathrm{X} 1$ =Working capital/Total asset

$\mathrm{X} 2=$ Net profit before interest and tax/Total asset

$\mathrm{X} 3=$ Return on asset (ROA)

Model Grover mengkategorikan perusahaan dalam keadaan bangkrut dengan skor kurang atau sama dengan - 0,02 $(Z \leq-0,02)$. Sedangkan nilai untuk 
perusahaan yang dikategorikan dalam keadaan tidak bangkrut adalah lebih atau sama dengan 0,01 ( $Z \geq 0,01)$ (Prihanthini \& Sari, 2013).

\section{Teknik Analisis Data}

Penelitian ini menggunakan data sekunder yang diperoleh dari laporan keuangan perusahaan yang terdaftar di Bursa Efek Indonesia selama periode 2012 sampai dengan 2016. Data di perol eh dari website I ndonesian Stock Exchange www.idx.co.id. Sesuai dengan tujuan penelitian, metode analisis data yang akan digunakan adalah analisis regresi logistik biner untuk mengetahui pengaruh variabel independen terhadap variabel dependen. Software yang akan digunakan adal ah program SPSS versi 20.0 J enis-jenis analisis data yang dilakukan meli puti analisis dan uji outl ier statistik deskriptif, uji multikolinearitas serta uji hipotesis yaitu uji Hosmer and Lemeshow, uji Wald uji dan uji Nagelkerke R Square yang dilakukan dengan pemilihan model terbaik.

Model regresi yang akan terbentuk dalam penelitian ini berdasarkan analisis regresi logistik adalah:

$Y=\alpha+\beta_{1} X_{1}+\beta_{2} X_{2}+\beta_{3} X_{3}+\beta_{4} X_{4}+e$

Keterangan:

$\alpha \quad=$ Konstan

$\beta \quad=$ Koefisien regresi

$Y=$ Financial Distress

$\mathrm{X}_{1}=$ Altman Z-score

$\mathrm{X}_{2}=$ Springatescore

$\mathrm{X}_{3}$ =Zmijewski score

$\mathrm{X}_{4} \quad=$ Grover score

\section{HASIL DAN PEMBAHASAAN}

Hasil uji analisis regresi berganda ditampilkan di tabel 1 berikut:

\begin{tabular}{lc}
\hline Keterangan & J umlah \\
\hline Perusahaan yang terdaftar di BEI & 560 perusahaan \\
Perusahaan yang laporannya tidak lengkap & 140 perusahaan \\
Perusahaan yang tidak memenuhi kriteria & 132 perusahaan \\
Perusahaan yang dijadikan sampel & 288 perusahaan \\
Tahun penelitian & 5 tahun \\
Total data perusahaan yang dipakai sebagai sampel & 1.440 data \\
penelitian & \\
Total data outlier & 119 data \\
Total data yang diuji dalam penelitian & 1.321 data \\
\hline
\end{tabular}

Tabel 1:

Daftar Perusahaan yang Dijadikan

Sampel

\section{Statistik Deskriptif}

Hasil uji analisis regresi berganda ditampilkan di tabel 2 berikut:

\begin{tabular}{lcrrr}
\hline \multirow{2}{*}{ Variabel } & \multicolumn{3}{c}{ Statistik Deskriptif } & \\
\cline { 2 - 5 } & Minimum & Maksimum & Rata-Rata & Std. Deviasi \\
\hline Altman & $-2,807$ & 59,330 & 4,04969 & 5,209792 \\
Springate & $-2,537$ & 8,673 & 1,02228 & 1,007685 \\
Zmijewski & $-5,478$ & 2,099 & $-1,84903$ & 1,339322 \\
Grover & $-1,048$ & 2,561 &, 61630 &, 568087 \\
Valid N (listwise) & 1321 & & & \\
\hline
\end{tabular}


Ketepatan

Model

Altman, Springate,...

86

Tabel 2 menunjukkan bahwa hasil statistik deskriptif dari skor model Altman terkecil adalah -2,807 yakni perusahaan Kertas Basuki Rachmat Indonesia Tbk merupakan perusahaan berkondisi paling buruk, sedangkan menurut model Springateskor terkecil adalah -2,537 yakni perusahaan Star Pacific Tbk merupakan perusahaan berkondisi paling buruk, skor tertinggi model Zimjwski adalah 2,099 yakni perusahaan Mitra Investindo Tbk berdasarkan model Zmijewski merupakan perusahaan berkondisi paling buruk, skor terkecil model Groveradalah -1,048 yakni perusahaan Ancora Indonesia Resources Tbk merupakan perusahaan berkondisi paling buruk.

Perusahaan berkondisi paling baik berdasarkan model Altman yakni Perusahaan Inti Agri Resources Tbk karena memiliki skor tertinggi sebesar 59,330. Perusahaan Pioneerindo Gourmet I nternational Tbk berdasarkan model Springate merupakan perusahaan berkondisi paling baik dengan skor sebesar 8,673, berdasarkan model Zmijewski perusahaan First Media Tbk merupakan perusahaan berkondisi paling baik dengan skor sebesar $-5,478$, sedangkan menurut model Grover perusahaan berkondisi paling baik adal ah perusahaan Delta Djakarta Tbk dengan skor 2,561.

Tabel 3:

Hasil Uji Statistik

Deskriptif Variabel Dummy
Tabel 4:

Hasil Uji

Multikolinearitas
Tabel 5:

Hasil Uji Hipotesis dengan Uji Hosmer and Lemeshow

\begin{tabular}{llcc}
\hline Variabel & Kategori & Frekuensi & Persentase \\
\hline Finacial Distress & O = Non-financial distress & 731 & $55,3 \%$ \\
& $1=$ Financal distress & 590 & $44,7 \%$ \\
\hline
\end{tabular}

\section{Hasil Uji Outlier}

Hasil Uji outlier pada nilai Z-score (standardized score) terhadap varaiabel independen dan variabel dependen disimpulkan bahwa dari 1440 data observasi sebanyak 119 data observasi dikeluarkan dari pengujian sampel dan tidak diteliti lebih lanjut lagi karena memiliki nilai diluar kewajaran.

\section{Hasil Multikolinearitas}

Hasil uji analisis regresi berganda ditampilkan di tabel 4 berikut:

\begin{tabular}{lccc}
\hline \multicolumn{1}{c}{ Variabel } & Tolerance & VIF & Keterangan \\
\hline Altman & 0,609 & 1,641 & Tidak Terjadi Multikolinearitas \\
Springate & 0,348 & 2,871 & Tidak Terjadi Multikolinearitas \\
Zmijewski & 0,555 & 1,800 & Tidak Terjadi Multikolinearitas \\
Grover & 0,291 & 3,442 & Tidak Terjadi Multikolinearitas \\
\hline
\end{tabular}

Berdasarkan uji multikol inearitas pada tabel diatas, diketahui nilai VIF pada semua variabel independen berada dibawah nilai 10, sehingga dapat disimpulkan bahwa tidak terjadinya korelasi antara variabel independen pada penelitian ini.

\section{Hasil Uji Hipotesis}

Pengujian hipotesis dilakukan dengan menggunakan regresi logit biner. Adapun hasil pengujian hipotesis disajikan sebagai berikut:

\section{Hasil Uji Hosmer and Lemeshow}

Hasil uji analisis regresi berganda ditampilkan di tabel 5 berikut:

\begin{tabular}{cccc}
\hline Step & Chi-square & df & Sig. \\
\hline 1 & 15,296 & 8 & 0,054 \\
\hline
\end{tabular}


Uji Hosmer and Lemeshow di atas menunjukkan nilai probabilitas untuk variabel dependen. Hasil pengujian mempunyai nilai signifikansi sebesar 0,054 lebih besar dari 0,05 yang artinya tidak diperoleh adanya perbedaan antara prediksi model regresi logistik dengan data hasil observasi. Maka disimpulkan data dal am penelitian ini sesuai dengan model penelitian sehingga model regresi layak digunakan untuk memprediksi variabel financial distress dan untuk melanjutkan pengujian dalam penelitian ini.

\section{Hasil Pengujian Hipótesis 1, 2, 3, dan 4 (Uji Wald)}

Uji regresi logit secara parsial dilakukan untuk mengetahui pengaruh dari masing-masing variabel variabel independen terhadap variabel dependen. Tingkat signifikansi variabel-variabel independen dalam penelitian harus l ebih kecil 0,05 terhadap variabel dependen. Hasil uji parsial (uji wald) dapat dillihat pada Tabel 6 di bawah ini:

\begin{tabular}{lcccc}
\hline Variabel & B & Sig. & Keterangan & Hipotesis \\
\hline Altman & 0,133 & 0,001 & Signifikan & Terbukti \\
Springate & $-8,314$ & 0,000 & Signifikan & Terbukti \\
Zmijewski & $-0,396$ & 0,000 & Signifikan & Terbukti \\
Grover & 2,814 & 0,000 & Signifikan & Terbukti \\
Constant & 4,020 & 0,000 & & \\
\hline
\end{tabular}

Tabel 6:

Hasil Uji Wald

Berdasarkan hasil pengujian diatas diketahui bahwa variabel Altman, Springate, Zmijewski dan Grover memiliki nilai signifikansi dibawah 0,05, sehingga dapat disimpulkan $\mathrm{H}_{1}$ diterima yang artinya model Altman dapa digunakan untuk memprediksi financial distress, hasil ini konsisten dengan Kutum (2015), Karamzadeh (2013), Diakomi hal is (2012). Model Springate dapat diginakan untuk memprediksi financial distress yang artinya $\mathrm{H}_{2}$ diterima, hasil ini konsisten dengan Sunaryo (2013), Rajasekar, Ashraf \& Deo (2014), Yadav dan Vijay (2015), Permana, Ahmar dan, Djaddang (2017).

Model Zmijewski dapat diginakan untuk memprediksi financial distress yang artinya $\mathrm{H}_{3}$ diterima, hasil ini konsisten dengan Djamaludddin, Putridan, dan Ali (2017), Husein dan Pambekti (2014), Layyinaturrobaniyah dan Dewi (2017) Gunawan, Pamungkas, dan Susilawati (2017). Model Grover dapat diginakan untuk memprediksi financial distress yang artinya $\mathrm{H}_{4}$ diterima, hasil ini konsisten dengan Prihantini dan Sari (2013), Hastuti (2014), Aminian, Mousazade dan Khoshkho (2016).

Persamaan regresi yang dibentuk pada pengujian hipotesis ini sebagai berikut:

$Y=4,020+0,133$ Altman - 8,314Springate-0,396Zmijewski $+2,814$ Grover + $1-0,746$

\section{Hasil Uji Model Summary (Nagelkerke R Square)}

Hasil uji analisis regresi berganda ditampilkan di tabel 7 berikut:

\begin{tabular}{llll}
\hline Step & $-2 \log$ Likehood & Cox Snell $R$ square & Nagelkerke $R$ Square \\
\hline 1 & $740,489 a$ & 0,557 & 0,746 \\
\hline
\end{tabular}

Tabel 7:

Hasil Uji Model

Summary

(Nagelkerke R

Square)

Tabel 7 menunjukkan nilai Nagelkerke R Square 0,746 atau $74,6 \%$ yang berarti variabel-variabel independen dapat menjelaskan variabel dependen sebesar $\mathbf{7 4 , 6 \%}$ sedangkan $\mathbf{2 5 , 4 \%}$ dijelaskan oleh faktor lain yang tidak terdapat dalam 


\section{Ketepatan \\ Model \\ Altman, Springate,...}

\section{8}

Tabel 8:

Hasil Uji Nagelkerke R Square setiap independen model. Penentuan model prediksi terbaik antara keempat model tersebut dilakukan dengan uji model summary tiap model pada tingkat nilai Nagelkerke R Square. Hasil pengujian tingkat akurasi model dapat dilihat di bawah ini:

\begin{tabular}{lc}
\hline \multicolumn{1}{c}{ Variabel Independen } & Nagelkerke $\boldsymbol{R}$ Square \\
\hline Altman & 0,120 \\
Springate & 0,697 \\
Zmijewski & 0,081 \\
Grover & 0,428 \\
\hline
\end{tabular}

\section{Hasil Pengujian Hipotesis Lima $\left(\mathrm{H}_{5}\right)$}

Hasil uji diatas diketahui bahwa nilai Nagelkerke R Square model Altman dapat di inter pretasi kan secara bersama bahwa variabel-variabel pada model Altman mampu menjelaskan variabel dependen sebesar 0,120 atau $12 \%$ sedangkan sisanya $88 \%$ dijelaskan ol eh variabel lain. Rasio likuiditas, rentabilitas, profitabilitas memiliki pengaruh paling penting dalam menentukan financial distress (Muniroh dan Suhar sono, 2016). Widiyana (2009) menambahkan rasio solvabilitas juga berpengaruh signifikan dalam model Altman. Nilai hasil R square Altman berada di bawah Springate dan Grover, tetapi bearada diatas model Zmijewski yang artinya $\mathrm{H}_{5}$ ditolak karena bukan merupakan prediktor terbaik financial distress.

\section{Hasil Pengujian Hipotesis Enam $\left(\mathrm{H}_{6}\right)$}

Hasil uji pada Tabel 8 diketahui bahwa nilai Nagelkerke R Square model Springate dapat diinterpretasikan secara bersama bahwa variabel-variabel pada model Springate mampu menjelaskan variabel dependen sebesar 0,697 atau 69,7\% sedangkan sisanya 30,3\% dijelaskan ol eh variabel lain. Rasio net profit before tax to total assets, net profit before tax to current liabilities dan sales to total assets berpengaruh signifikan pada model Springate (Puspitaningrum \& Purnamasari, 2016). Nilai hasil R square Springate berada di atas model Altman, Zmijewski dan Grover yang artinya $\mathrm{H}_{6}$ diterima karena merupakan prediktor terbaik financial distress.

Model Springate memiliki rasio earning beforetax to current liabilities rasio ini digunakan untuk mengukur kemampuan perusahaan dalam menghasilkan laba yang digunakan untuk menutupi hutang jangka pendek dan mencerminkan kondisi perusahaan melalui tingkat laba, biaya operasi dan pembayaran hutang (M eiliawati, 2016). Rasio earning before interest and taxes to total assets dan earning before tax to current liabilities secara signifikan ber pengaruh terhadap delisting (Sunaryo, 2013). Hasil ini sejal an dengan Meita (2016) Syafitri dan Triniadi (2016) I manzadeh dan Sepehri (2011), bahwa model Springate merupakan model terbaik.

\section{Hasil Pengujian Hipotesis Tujuh $\left(\mathrm{H}_{7}\right)$}

Hasil uji Tabel 8 diketahui bahwa nilai NagelkerkeR Squaremodel Zmijewski cukup rendah yakni hanya sebesar 0,081 atau 8,1\% sedangkan sisanya 91,9\% dijel askan ol eh variabel lain. H anya rasiototal debt to total assets yang berpengaruh secara signifikan, sedangkan dua rasio lainnya dalam model Zmijewski yakni net profit after taxes to total assets dan current assets to current liabilities kurang berpengaruh secara signifikan (Puspitaningrum \& Purnamasari, 2016). Nilai hasil R square Zmijewski berada di bawah model Altman, Springate dan Grover yang artinya $\mathrm{H}_{7}$ ditolak karena bukan merupakan prediktor terbaik financial distress. 
Hasil uji Tabel 8 diketahui bahwa nilai Nagelkerke $R$ Square model Grover sebesar 0,428 atau $42,8 \%$ sedangkan sisanya $57,2 \%$ dijelaskan oleh variabel lain. Model Grover tidak memiliki komponen hutang, padahal komponen hutang sangat penting untuk memprediksi kesulitan keuangan karena akan menunjukkan kemampuan perusahaan dalam membayar hutang. Selain itu juga tidak ada rasio sales to total assets yaitu seberapa besar kemampuan aset dalam meningkatkan penjualan perusahaan (Permana, Ahmar \& Djaddang, 2017). Nilai hasil $R$ square Grover berada di bawah Springate, tetapi bearada diatas model Altman dan Zmijewski yang artinya $\mathrm{H}_{8}$ ditolak karena bukan merupakan prediktor terbaik financial distress.

\section{SIMPULAN}

\section{Kesimpulan}

Penelitian ini menguji tingkat ketepatan dan perbandingan model-model financial distress. Berdasarkan hasil analisis dan pembahasaan pada bagian sebelumnya disimpulkan bahwa setiap model yang yang ada dalam penelitian ini berpengaruh signifikan yang artinya model Altman, Springate, Zmijewski, dan Grover bisa digunakan dalam memprediksi financial distress. Model Springate merupakan model prediksi terbaik untuk financial distress diantara model lainnya karena memiliki tingkat akurasi tertinggi berdasarkan hasil uji koefisien determinasi yakni sebesar 69,7\% kemudian diikuti oleh model Grover, Altman, dan Zmijewski.

Keterbatasan dalam penelitian ini adalah hanya sekedar membandingkan model tetapi tidak memperhatikan rasio variabel-variabel pada setiap model, yang tidak dilakukan pada penelitian kali ini karena hanya berfokus pada pembuktian model.

Adapun rekomendasi yang dapat peneliti berikan kepada peneliti selanjutnya yang tertarik untuk meneliti lebih lanjut lagi mengenai financial distress, diharapkan dapat menambahkan model financial ditress yang lain seperti Ohlson, Fulmer CA-score, dan yang lainnya atau dapat membandingkan rasiorasio pada model Springate maupun model lainnya yang manakah merupakan rasio paling berpengaruh untuk memprediksi financial distress.

\section{DAFTAR PUSTAKA}

Altman, E. I. (1968). "Financial Ratios, Discriminant Analysis and the Prediction of Corporate Bankruptcy". The Journal of Finance. Vol 23 No 4.

Aghajani, V., dan Jouzbarkand, M. (2012). "The Creation Of Bankruptcy Prediction Model Using Springate and SAF Models". International Proceedings of Economics Development and Research. Vol 54 No 2. DOI: 10.7763/IPEDR.

Alareeni., Bahaaedin., dan Branson, J., (2013). 'Predicting Listed Companies'. Failure in Jordan Using Altman Models: A Case Study". International. Journal of Business and Management. Vol 8 No 1.

Almilia, L. S., \& Kristijadi, E. (2003). “Analisis Rasio Keuangan Untuk Memprediksi Kondisi Financial Distress Perusahaan Manufaktur Yang Terdaftar di Bursa Efek Jakarta”. Jurnal Akuntansi \& Auditing Indonesia. Vol 7 No 2.

Al-Sulaiti, K.I., dan Almwajeh, O. (2007). "Applying Altman Z-score model of bankruptcy on service organizations and its implications on marketing concepts and strategies". Journal of InternationalMarketing \& Marketing Research. Vol 32 No 2. 
Ketepatan

Model

Altman,

Springate,...

90
Aminian, A., Mousazade, H., dan Khoshkho, O. I . (2016). “Investigate the Ability of Bankruptcy Prediction M odels of Altman and Springate and Zmijewski and Grover in Tehran Stock Exchange". Mediterranean J ournal of Social.Vol 7 No 4.

Anggarini, T. V. dan M. D. Ardiyanto. (2010). "Pengaruh Karakteristik Komite Audit Terhadap F inancial Distress". E-journal Universitas Dipponegoro.

Brimantyo.,Topowijono., dan Husaini, A.S. (2012). “Penerapan Anal isis Altman ZScore Sebagai Salah Satu Alat Untuk Mengetahui Potensi Kebangkrutan Perusahaan Pada perusahaan Telekomunikasi Yang Listing di BEI Periode Tahun 2009-2011". J urnal Administrasi Bisnis. Vol 1 No 1.

Diakomihalis, M. N . (2012). “The Accuracy of Altman's M odels in Predicting H otel Bankruptcy. International J ournal of Accounting and Financial Reporting". Vol 2 No 2.

Djamaluddin, S., Putridan M.J . dan Ali, H. 2017. "Financial Distress Comparative Analysis of J apanese Electronic Manufacturer after Financial Global Crisis 2008 Using Altman, Ohlson, and Zmijewski Model". The International J ournal Of Business \& Management. Vol 5 No 7.

Eidleman, G. J . (1995). "Z-Scores - A Guide to F ailure Prediction". The CPA J ournal Online. Vol 65 No 2.

Grice, J . S. dan Dugan, M. T. (2003). "Re-estimations of the Zmijewski and Ohlson bankruptcy prediction models". Advances in Accounting. Vol 20.

Gunathilaka, C. (2014). "Financial Distress Prediction: A Comparative Study of Solvency Test and Z-Score Models with Reference to Sri Lanka". The IUP J ournal of Financial Risk Management. Vol 9 No 3.

Gunawan, B., Pamungkas, R., dan Susilawati, D. (2017). “Perbandingan Prediksi Financial Distress Menggunakan Model Altman, Grover dan Zmijewski". J urnal Akuntansi Dan Investasi. Vol 18 No 1.

Hastuti. (2015). "Analisis komparasi model Altman, Springate, Grover dan OhIson pada perusahaan manufaktur". J urnal Ekonomi. Vol 20 No 3.

Hayes, S. K., Hodge, K.A., dan Hughes, L. W. (2010). "A Study of the Efficacy of Altman's ZTo Predict Bankruptcy of Specialty Retail Firms Doing Business in Contemporary Times". Economics \& Business J ournal. Vol $3 \mathrm{Nol}$.

Husein, M., F., dan Pambekti, G. T. (2014). "Precision of the models of Altman, Springate, Zmijewski, and Grover for predicting the financial distress". J ournal of Economics, Business, and Accountancy Ventura. Vol 17 No 3. https:// doi.org/10.14414/jebav. 14.1703010

I manzadeh, P., Maran-J ouri, M., dan Sepehri, P. (2011). "A Study of the Application of Springate and Zmijewski Bankruptcy Prediction Models in Firms Accepted in Tehran Stock Exchange". Australian J ournal of Basic and Applied Sciences, Vol 5 No 11.

Karamzadeh, M. S. (2013). "Application and comparison of altman and ohlson models to predict bankruptcy of companies". Research J ournal of Applied Sciences, Engineering and Technology. Vol 5 No 6.

Kutum., I . (2015). "Predicting the Financial Distress of N on-Banking Companies". Research J ournal of Finance and Accounting. Vol 6 No 10.

Layyinaturrobaniyah dan Dewi, K., R. 2017. "Analisis Prediksi Financial Distress Berdasarkan Model Altman Dan Zmijewski Pada Perusahaan Manufaktur YangTerdaftar Di Bursa E fek I ndonesia".J urnal Ekonomi dan BisinisTerapan. Vol 13 No 1.

Luciana, S. A. dan Kristijadi, E. (2003). “Analisis Rasio Keuangan Untuk Memprediksi Kondisi Financial Distress Perusahaan Manufaktur Yang Terdaftar di Bursa Efek J akarta". J urnal Akuntansi \& Auditing Indonesia. Vol 7 No 2. 
Meiliawati, A. (2016). "Anal isis Perbandingan Model Springate dan Altman ZScore terhadap Potensi Financial Distress (Studi Kasus pada Perusahaan Sektor Kosmetik yang Terdaftar di Bursa Efek Indonesia)". J urnal Akuntansi Dan Pendidikan. Vol 5 no 1.

Meita, E. (2016). "Analisis Penggunaan MetodeAltman, Springate, dan Zmijewski. dalam Memprediksi Kebangkrutan Perusahaan Pertambangan Batubara". J urnal Mahasiswa UNESA.

Mohammed, A. A. E. dan Kim-soon, N. (2012). “Using Altman Model and Current Ratio to Assess the Financial Status of Companies Quoted In the Malaysian Stock Exchange". International J ournal of Scientific and Research Publications. Vol 2 No 7.

Permana, R. K., Ahmar, N., dan Djadang, S. (2017). “Prediksi Financial Distress Pada Perusahaan Manufaktur Di Bursa E fek Indonesia." Esensi : J urnal Bisnis Dan Manajemen, 7(2),

Platt, H. dan Platt, M. B. (2002). “Predicting Financial Distres."J ournal of

Financial Service Professionals. Vol 56.

Prabowo, R. dan Wibowo. 2015. "Analisis Perbandingan Model Altman Z-Score, Zmijewski, dan Springate dalam Memprediksi Kebangkrutan Perusahaan Delisting Di BEI Periode 2008 - 2013 “. J urnal Akuntansi, Keuangan dan Perbankan. Vol 1 No 3.

Prihathini N. dan Ratna Sari. 2013. “Prediksi kebangkrutan dengan model Grover, Altman ZScore, Springate dan Zwijewski pada perusahaan Food and Beverage di Bursa Efek Indonesia". E J urnal Akuntansi Universitas U dayana. ISSN 2302-8556.

Putra, I. G. S. dan Septiani, R. (2017). “Analisis Perbandingan Model Zmijewski Dan Grover Pada Perusahaan Semen Di Bei 2008-2014". J urnal Riset Akuntansi Dan Keuangan. Vol 4 No 3.

Qitshi, D., Suhadak., dan Handayani, S., R. (2013). "Analisis X-Score (Model Zmijewski) untuk Memprediksi Gejala Kebangkrutan Perusahaan (Pada Industri Otomotif dan Komponennya)". J urnal Administrasi Bisnis. Vol 1 No 2.

Rajasekar, T. (2014). "An E mpirical Enquiry on the Financial Distress of Navratna Companies in I ndia". J ournal of Accounting and Finance. Vol 14 No 13.

Reddy, M. D., dan Prasad, K.V.N. (2011). "Financial Health Of Hdfc: A CaseStudy". Asian journal of research in banking and finance. Vol 1 No. ISSN : 2249-7323.

Rhomadhona, M. N. (2014). “Anal isis Perbandingan Kebangkrutan M odel Altman, Model Springate, Dan Model Zmijewski Pada Perusahaan Yang Tergabung Dalam Grup Bakrie Yang Terdaftar Di Bursa Efek Indonesia Periode 20102012". J urnal Universitas N egeri Surabaya.

Sembiring, T. M. (2015). "Bankruptcy Prediction Analysis of Manufacturing Companies Listed in Indonesia Stock Exchange". International J ournal of E conomics and Financial Issues. Vol 5.

Sheikhi, M., Fallah Shams, M., dan Sheikhi, Z. (2011). "Financial Distress Prediction Using Distress Score as a Predictor". International J ournal of Business and Management. Vol $7 \mathrm{No} 1$.

Sunaryo. (2015). “Evaluasi Tingkat Keakuratan Antara Model Springate Dengan Model Altman Dalam M emprediksi Delisting Perusahaan Manufaktur Yang Terdaftar Di Bursa Efek I ndonesi a". J ournal of Business Strategy and Execution. Vol 7 No 2.

Tirapat, S., \& Nittayagasetwat, A. (1999). “An Investigation of Thai Listed Firms' Financial Distress Using Macroand MicroVariables". Multinational Finance J ournal. Vol 3 No 2. 
Ketepatan Model

Altman, Springate,...
Tyagi, V. (2014). “A Study To Measures The Financial Health Of Selected Firms With Special ReferenceTo Indian L ogistic Industry/: An Application of Altman's Z Score". IISTE J ournals. Vol 4 No 4. pp. 43-53. ISSN 2225-0581.

Yadav, C. S., dan Vijay, P. (2015). "Predicting Bankruptcy: An E mpirical Study U sing Multiple Discriminant Analysis Models". PezzottaiteJ ournals. Vol 4 Nol.

Zmijewski, M. E. (1984). "M ethodological I ssues Relate to the Estimation of Financial of Financial Distress Prediction M odels". J ournal of Accounting Research. Vol 2. 